\title{
CHANGES IN THE BLOOD AND CIRCULATION WITH CHANGES \\ IN POSTURE. THE EFFECT OF EXERCISE \\ AND VASODILATATION
}

\author{
By JOHN B. YOUMANS, J. H. AKEROYD, JR., AND HELEN FRANK \\ (From the Department of Medicine, Vanderbilt University Medical School, Nashville)
}

(Received for publication May 31, 1935)

In the erect posture the forces tending to filter fluid from the blood into the tissues of the dependent parts are much greater than in the recumbent position. As Krogh, Landis and Turner have remarked, the erect human being is always close to edema (1). In a previous study of the effect of quiet standing (2) it was pointed out that the primary factors concerned in limiting the loss of fluid from the blood in the standing-still position appear to be an increasing concentration of plasma proteins, with a resulting rise in colloid osmotic pressure ${ }^{1}$ and, probably, an increasing tissue pressure. However, secondary factors, changes in the circulation especially, modify this mechanism, particularly under conditions of normal activity. The changes may be the direct result of the change in posture, as for example the vasoconstriction which apparently accompanies the change in position. They may be the result of other influences such as exercise, or variations in environmental temperature. Under abnormal conditions, such as a nutritional hypoproteinemia, and particularly in border line states of such a disorder, variations in these factors might determine the occurrence or non-occurrence of edema. Therefore, we have studied the effect of some of these secondary factors on the circulation in the legs and on changes in the composition of the blood which occur in the erect position. The present paper deals with (1) the effect of muscular activity on the changes in the blood resulting from the erect posture, (2) changes in the circulation in the feet and legs in the erect posture, quiet and moving, as shown by changes in the surface temperature, (3) a comparison of the circulation time in the quiet and moving leg in the erect posture, and (4) the influence of vasodilatation

1 The increase in colloid osmotic pressure is greater than the increase in concentration of the proteins because of the increase in specific osmotic pressure, i.e., pressure per gram of protein. on the changes in the composition of the blood which occur on standing. For convenience in presentation, the methods and data in each of the studies will be presented separately.

\section{THE EFFECT OF MUSCULAR ACTIVITY ON THE CHANGES IN THE BLOOD RESULTING FROM THE ERECT POSTURE}

The influence of muscular activity was determined by comparing the changes in the composition of the blood and in the leg volume of an actively moving leg in the erect posture with those of the opposite leg which was kept motionless. In addition a few observations were made of the capillaries in the great toe of the quiet leg.

The subjects consisted of six young healthy men (students) and one man with nutritional edema. About an hour. after a light lunch the subject reclined for 60 minutes or more. During this time the capillaries at the base of the great toe nail were observed with a capillary microscope. At the end of the reclining period a sample of blood was drawn from the arm. ${ }^{2}$ After the blood was drawn the venous pressure was measured directly. The volume of each leg was then determined by measuring the amount of water displaced from a rigid metal boot reaching to about the knee $(48.3 \mathrm{~cm}$.). The temperature of the water was adjusted to approximately room temperature. After the immersion the leg was quickly dried without rubbing. Each measurement occupied approximately five minutes and the subject reclined five minutes between the measurements of the first and second legs. After the volume of the second leg was measured the subject again reclined for a period of five to ten minutes. The subject then mounted a stationary bicycle, the left pedal of which was removed. The left leg was allowed to hang

\footnotetext{
${ }^{2}$ It is assumed that during reclining, blood from the foot has the same composition as blood from the arm (2).
} 
perpendicularly, supported comfortably in half the experiments by a platform and unsupported in the others. The subject began to pedal immediately with the right leg against a resistance which was obtained by means of an adjustable spool pressing against the partially deflated tire of the rear wheel. The position assumed is believed to be comparable, as far as the left (motionless) leg is concerned, to standing at an angle of 75 degrees as employed in previous experiments (2). Pedalling was continued at a rate of forty to fifty revolutions per minute except for short interruptions to allow for the inspection of the capillaries in the toe of the motionless foot. When the latter was allowed to hang unsupported, it was supported temporarily while the capillaries were observed. When the right leg was not pedalling it was stopped at the mid point between the top and bottom of the stroke. Total pedalling time was thirty minutes but the time the subject was on the bicycle varied because of the time taken out for capillaroscopy and the drawing of samples of blood at the end of the period of pedalling. When the subject had pedalled for thirty minutes a sample of blood was drawn from each foot from a vein on the dorsum or at the internal malleolus. The sample from the right (moving) foot was always drawn first and the venous pressure was determined in the left foot. The volume of each leg was then measured again. Because of difficulties sometimes encountered, the time relation of the various procedures, particularly the time elapsing between the cessation of pedalling, the obtaining of the two samples of blood and the final measurement of leg volume, was not the same in all the experiments. The samples of blood were drawn under oil without stasis, and with heparin as an anticoagulant; specimens were removed for determining the concentration of plasma proteins, the colloid osmotic pressure and the nonprotein nitrogen. The methods of analysis were the same as those described in a previous paper (2).

The results of the experiments are summarized in Table I. In four experiments the increase in the concentration of total proteins both actual and percentile, was greater in the " motionless" (left) leg than in the " moving" (right) leg. ${ }^{3}$ In two,

3 This is believed not to be the result of a lessened tendency to filtration, resulting from the intermittent na- the increase was practically the same in each leg, the differences being within the limit of error. Absence of a greater difference between the two legs in some of the experiments may have been the result of such irregularities as delay in drawing samples of blood and fainting of the subject. The changes in the concentration of albumin were similar, the one instance in which the increase in concentration of albumin was greater in the " moving" leg than in the "quiet" leg occurring in the experiment in which the increase in total protein was slightly greater in the moving leg. In two instances the concentration of globulin was greater in the moving than in the quiet leg. When the percentile increase of total protein and of the two fractions are compared discrepancies are found which suggest that variable amounts of either albumin, globulin or both were lost through the vessel wall. There is no evidence, however, of any consistency in respect to the amount or kind of protein which escaped. This lack of consistency is in accord with the observations of Landis and his associates (3).

In every experiment the increase in colloid osmotic pressure of the blood was greater in the "quiet" leg, but in Subject $\mathrm{H}$ the difference was very slight, almost within the limit of experimental error. The increase in leg volume was greater in the "quiet" leg than in the "moving" leg in all the experiments. In two experiments, the right or "moving" leg not only failed to show as great an increase in volume as the left but showed an actual decrease compared with its volume during the reclining period. In one of these two experiments the subject was the patient with edema. Although the method of measuring leg volume is not very accurate, the limit of error, which is believed to be within ten or fifteen cc., is much less than the changes in volume of the two legs or than the differences in change of volume between the two legs, even in those experiments in which a decrease in volume of the " moving" leg was found.

No study was made of the quantitative changes in the capillaries in the left (quiet) foot but the

ture of the venous pressure in the moving leg, the somewhat smaller hydrostatic pressure during part of the cycle of movement, or the effect on leg volume of a possibly lessened filling of the blood vessels in the moving leg. 
TABLE I

The concentration of plasma proteins, colloid osmotic pressure, venous pressure, and volume of the leg in the reclining position and in the quiet and moving legs in the erect posture

\begin{tabular}{|c|c|c|c|c|c|c|c|c|c|c|c|c|c|}
\hline \multirow{3}{*}{ Subject } & \multirow{3}{*}{ Position $†$} & \multicolumn{6}{|c|}{ Serum proteins } & \multirow{2}{*}{\multicolumn{2}{|c|}{$\begin{array}{l}\text { Osmotic } \\
\text { pressure }\end{array}$}} & \multirow{2}{*}{\multicolumn{2}{|c|}{$\begin{array}{c}\text { Leg } \\
\text { volume }\end{array}$}} & \multirow{3}{*}{$\begin{array}{l}\text { Ve- } \\
\text { nous } \\
\text { pres- } \\
\text { sure }\end{array}$} & \multirow{3}{*}{ Remarks } \\
\hline & & \multicolumn{2}{|c|}{ Total } & \multicolumn{2}{|c|}{ Albumin } & \multicolumn{2}{|c|}{ Globulin } & & & & & & \\
\hline & & & \begin{tabular}{|c|} 
In- \\
crease
\end{tabular} & & $\begin{array}{c}\text { In- } \\
\text { crease }\end{array}$ & & \begin{tabular}{c|} 
In- \\
crease
\end{tabular} & & $\begin{array}{c}\text { In- } \\
\text { crease }\end{array}$ & & $\begin{array}{c}\text { In- } \\
\text { crease }\end{array}$ & & \\
\hline B. D. & $\begin{array}{c}\text { Reclining } \\
\text { Erect }{ }_{L}^{R}\end{array}$ & $\begin{array}{c}\text { grams } \\
\text { per } \\
\text { cent } \\
6.83 \\
\\
7.64 \\
7.88\end{array}$ & \begin{tabular}{|l|}
11.9 \\
15.4
\end{tabular} & $\begin{array}{c}\text { grams } \\
\text { per } \\
\text { cent } \\
4.75 \\
\\
5.32 \\
5.36\end{array}$ & $\begin{array}{l}12.0 \\
12.8\end{array}$ & $\begin{array}{c}\text { grams } \\
\text { per } \\
\text { cent } \\
2.08 \\
\\
2.32 \\
2.52\end{array}$ & $\begin{array}{l}11.5 \\
21.1\end{array}$ & $\begin{array}{l}\mathrm{CH}_{2} \mathrm{O} \\
34.4 \\
40.5 \ddagger \\
42.0 \ddagger\end{array}$ & $\begin{array}{l}17.8 \\
22.1\end{array}$ & $\begin{array}{r}\text { cc. } \mathrm{H}_{2} \mathrm{O} \\
\mathrm{R} 3580 \\
\mathrm{~L} 3490 \\
3595 \\
3590\end{array}$ & $\begin{array}{r}15 \\
100\end{array}$ & $\begin{array}{c}\underset{c m}{c m} . \\
H_{2} \mathrm{O} \\
11.7 \\
\\
112.8\end{array}$ & $\begin{array}{l}\text { Delay in drawing blood } \\
\text { samples from feet } \\
\text { Fainted }\end{array}$ \\
\hline S. B. & $\begin{array}{c}\text { Reclining } \\
\text { Erect }{ }_{L}^{R}\end{array}$ & $\begin{array}{l}6.65 \\
7.24 \\
7.31\end{array}$ & $\begin{array}{l}8.9 \\
9.9\end{array}$ & $\begin{array}{l}4.76 \\
5.22 \\
5.36\end{array}$ & $\begin{array}{r}9.7 \\
12.6\end{array}$ & $\begin{array}{l}1.89 \\
\\
2.02 \\
1.95\end{array}$ & $\begin{array}{l}6.8 \\
3.2\end{array}$ & $\begin{array}{l}35.3 \\
43.3 \\
44.0\end{array}$ & $\begin{array}{l}22.7 \\
24.6\end{array} \mid$ & $\begin{array}{r}\text { R } 3430 \\
\text { L } 3490 \\
3433 \\
3565\end{array}$ & $\begin{array}{r}3 \\
75\end{array}$ & $\begin{array}{r}8.3 \\
111.5\end{array}$ & $\begin{array}{l}\text { Fainted } \\
\text { Vomited }\end{array}$ \\
\hline J. D. & $\begin{array}{c}\text { Reclining } \\
\text { Erect }{ }_{\mathrm{L}}^{\mathrm{R}}\end{array}$ & $\begin{array}{l}6.84 \\
7.86 \\
9.21\end{array}$ & \begin{tabular}{|l|}
14.9 \\
34.6
\end{tabular} & $\begin{array}{l}5.15 \\
6.08\end{array}$ & $\begin{array}{l}14.7 \\
35.4\end{array}$ & $\begin{array}{l}2.35 \\
2.71 \\
3.13\end{array}$ & $\begin{array}{l}15.3 \\
33.2\end{array}$ & $\begin{array}{l}34.7 \\
\\
42.5 \\
55.4\end{array}$ & $\begin{array}{l}21.6 \\
59.7\end{array}$ & $\begin{array}{r}\mathrm{R} 5420 \\
\mathrm{~L} 5175 \\
5310 \\
5240\end{array}$ & $\begin{array}{c}-110^{*} \\
65\end{array}$ & 116.1 & \\
\hline H. G. & $\begin{array}{c}\text { Reclining } \\
\text { Erect }{ }_{\mathrm{L}}^{\mathrm{R}}\end{array}$ & $\begin{array}{l}6.50 \\
7.43 \\
8.16\end{array}$ & \begin{tabular}{|l|}
14.3 \\
25.5
\end{tabular} & $\begin{array}{l}4.83 \\
5.46 \\
5.90\end{array}$ & $\begin{array}{l}13.0 \\
22.2\end{array}$ & $\begin{array}{l}1.67 \\
1.97 \\
2.26\end{array}$ & $\begin{array}{l}17.9 \\
35.3\end{array}$ & $\begin{array}{l}34.2 \\
\\
42.4 \\
47.0\end{array}$ & $\begin{array}{l}24.0 \\
37.4\end{array}$ & 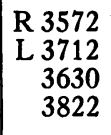 & $\begin{array}{r}58 \\
110\end{array}$ & $\begin{array}{r}5.4 \\
111.0\end{array}$ & \\
\hline R. H. & $\begin{array}{c}\text { Reclining } \\
\text { Erect }{ }_{\mathrm{L}}^{\mathrm{R}}\end{array}$ & $\begin{array}{l}6.70 \\
7.47 \\
7.42\end{array}$ & $\begin{array}{l}11.5 \\
10.7\end{array}$ & $\begin{array}{l}4.85 \\
5.44 \\
5.33\end{array}$ & $\begin{array}{r}12.2 \\
9.9\end{array}$ & $\begin{array}{l}1.85 \\
2.03 \\
2.09\end{array}$ & $\begin{array}{r}9.7 \\
13.0\end{array}$ & $\begin{array}{l}36.1 \\
41.3 \\
42.5\end{array}$ & $\begin{array}{l}14.4 \\
17.7\end{array}$ & \begin{tabular}{|r|}
$\mathrm{R} 4140$ \\
$\mathrm{~L} 4050$ \\
4220 \\
4200
\end{tabular} & $\begin{array}{r}80 \\
150\end{array}$ & $\begin{array}{r}10.0 \\
109.4\end{array}$ & $\begin{array}{l}\text { Delay in drawing blood } \\
\text { from right leg } \\
\text { Fainted, vomited } \\
\text { Blood pressure, } 60 / 40\end{array}$ \\
\hline F. I. & $\begin{array}{l}\text { Reclining } \\
\text { Erect }{ }_{\mathrm{L}}^{\mathrm{R}}\end{array}$ & $\begin{array}{l}6.20 \\
7.14 \\
7.35\end{array}$ & \begin{tabular}{|l|}
15.1 \\
18.5
\end{tabular} & $\begin{array}{l}4.11 \\
4.63 \\
5.00\end{array}$ & $\begin{array}{l}12.7 \\
21.4\end{array}$ & $\begin{array}{l}2.09 \\
2.51 \\
2.35\end{array}$ & \begin{tabular}{|l|}
20.1 \\
12.4
\end{tabular} & $\begin{array}{l}29.5 \\
36.5 \\
38.8\end{array}$ & $\begin{array}{l}23.7 \\
31.5\end{array}$ & $\begin{array}{r}\text { R } 4360 \\
\text { L } 4410 \\
4310 \\
4570\end{array}$ & $\begin{array}{c}-50^{*} \\
160\end{array}$ & 125.7 & \\
\hline
\end{tabular}

* Decrease.

$\dagger \mathrm{R}=$ Right leg; $\mathrm{L}=$ Left leg.

$\ddagger$ Calculated osmotic pressure using formula of Wells, Youmans and Miller (J. Clin. Invest., 1933, 12, 1103).

following qualitative changes were observed. During the reclining period the observable capillaries were usually rather few in number; the arterial and venous limbs were of about the same diameter, rather narrow and light red in color. The blood flow through them was relatively rapid. With the subject on the bicycle the number of visible capillaries rapidly increased. At the same time the diameter of the loops increased, that of the venous more than the arterial, with the former often appearing engorged with blood. The color of the blood became much darker and the flow slower. These changes increased as time elapsed. In one subject ( $H$. G.) the arterial limbs became greatly constricted toward the end of the experiment, and in another (R. H.) it was noted that when venipuncture was performed in that leg the capillaries "collapsed" (became constricted?). The subject with edema had fewer visible capillaries in the reclining position than the normal subjects, and when he mounted the bicycle, though more capillaries became visible, the cyanosis was less and the increase in the size of the venous loop over that of the arterial was less.

\section{Summary}

In the erect posture active muscular movements of the leg are accompanied by less concentration and less rise in colloid osmotic pressure of the blood in the moving leg than in the other leg kept motionless. At the same time there is a smaller 
increase in the volume of the moving leg, and, in some cases, an actual decrease compared with its volume in the reclining position. In the quiet leg in the erect posture the capillaries of the toe are dilated and the number of open capillaries increased.

\section{CHANGES IN THE CIRCULATION IN THE FEET AND LEGS, QUIET AND ACTIVE, AS SHOWN BY CHANGES IN THE SURFACE TEM PERATURE}

Changes in the circulation in the feet and legs under different conditions of posture, exercise and temperature were studied by observing the changes in the surface temperature.

The subjects were young, healthy, men and women. The following general procedure was followed with certain variations which will be described below. The subjects reclined with the feet and legs exposed to above the knees for an hour or so. During this period the surface temperature of the feet and legs, at the base of the great toe, over the external malleolus and over the mid leg on the anterior surface, was recorded with

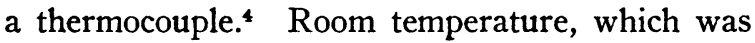
maintained as constant as possible, with a variation of about one degree centigrade, was measured with a mercury thermometer suspended near the feet and legs. After the surface temperature of the feet and legs had become relatively constant the subject stood as quietly erect as possible for periods of 60 to 75 minutes, and the surface temperatures were recorded at frequent intervals. Contact of the feet with the floor was prevented by a blanket. After the standing period the subjects again reclined, and the changes in surface temperature were followed. In most of the experiments the environmental temperatures were

\footnotetext{
4 The instrument used was a Tycos "Dermatherm." Freeman and Linder (Arch. Int. Med., 1934, 54, 981) have recently pointed out the relatively large errors which may occur in measurements of surface temperature with a thermocouple. We are cognizant of these possible errors and have controlled them as far as possible. Care was taken that exactly the same spot was tested each time. Although equilibrium of the skin with the surrounding air may not always have been reached during the preliminary period, in view of the consistency and magnitude of the changes the results are believed to be significant.
}

rather high, 28 to $30^{\circ} \mathrm{C}$. Some of the experiments were performed in a constant temperature room at temperatures of 19 to $24^{\circ} \mathrm{C}$.

In order to compare the effect of exercise and quiet standing on the surface temperature of the feet and legs, the following experiment was performed. After the initial period of reclining the subject mounted a stationary bicycle so arranged that he was able to stand nearly erect and quietly on the left leg while pedalling against an adjustable resistance with the right. Pedalling was continued for approximately one hour, except for brief periods to determine the surface temperatures which were measured at intervals of about five minutes in each leg. At the end of the period on the bicycle the subject again reclined, and the changes in the surface temperature were followed further.

The results are summarized in Tables II and III, and typical examples are illustrated in the accompanying charts. In nearly every instance the assumption of the standing-still posture was followed by a drop in the surface temperature of the toe (Table II) (Figure 1). As a rule, the

TABLE II

Changes in the surface temperature of the feet (toe) during quiet standing

\begin{tabular}{|c|c|c|c|c|c|c|c|}
\hline$\underset{\text { ject }}{\text { Sub- }}$ & $\begin{array}{l}\text { Room tem- } \\
\text { perature }\end{array}$ & $\begin{array}{l}\text { Tem- } \\
\text { pera- } \\
\text { ture } \\
\text { before } \\
\text { stand- } \\
\text { ing }\end{array}$ & $\begin{array}{c}\text { Lowest } \\
\text { tem- } \\
\text { pera- } \\
\text { ture } \\
\text { while } \\
\text { erect }\end{array}$ & $\begin{array}{c}\text { Maxi- } \\
\text { mum } \\
\text { de- } \\
\text { crease }\end{array}$ & $\begin{array}{l}\text { Time to } \\
\text { reach } \\
\text { lowest } \\
\text { tem- } \\
\text { pera- } \\
\text { ture }\end{array}$ & $\begin{array}{l}\text { Tem- } \\
\text { pera- } \\
\text { ture at } \\
\text { end of } \\
\text { stand- } \\
\text { ing }\end{array}$ & $\begin{array}{c}\text { Standing } \\
\text { time }\end{array}$ \\
\hline & ${ }^{\circ} \mathrm{C}$ & ${ }^{\circ} C$. & ${ }^{\circ} C$. & ${ }^{\circ} \mathrm{C}$. & minutes & ${ }^{\circ} \mathrm{C}$. & minutes \\
\hline $\begin{array}{l}\text { H. G. } \\
\text { E. W. } \\
\text { A. D. } \\
\text { V. S. } \\
\text { P. D. }\end{array}$ & $\begin{array}{l}28.8 \text { to } 29.3 \\
28.7 \text { to } 29.3 \\
28.8 \text { to } 29.3 \\
28.7 \text { to } 29.3 \\
28.8 \text { to } 29.2\end{array}$ & $\begin{array}{l}34.0 \\
31.9 \\
32.5 \\
32.0 \\
32.3\end{array}$ & $\begin{array}{l}32.0 \\
31.6 \\
30.1 \\
29.6\end{array}$ & $\begin{array}{l}2.0 \\
\\
0.9 \\
1.9 \\
2.7\end{array}$ & $\begin{array}{l}70 \\
47 \\
21 \\
61\end{array}$ & $\begin{array}{l}32.8 \\
32.6 \\
32.2 \\
30.8 \\
30.0\end{array}$ & $\begin{array}{l}75 \\
61 \\
71 \\
73 \\
76\end{array}$ \\
\hline $\begin{array}{l}\text { V. S. } \\
\text { A. D. } \\
\text { P. D. } \\
\text { J. Y. } \\
\text { H. F. } \\
\text { M. C. }\end{array}$ & $\begin{array}{l}22.0 \text { to } 24.0 \\
23.5 \text { to } 24.5 \\
24.8 \text { to } 25.5 \\
19.0 \text { to } 22.0 \\
19.5 \text { to } 21.0 \\
19.5 \text { to } 21.0\end{array}$ & $\begin{array}{l}26.1 \\
27.7 \\
29.8 \\
28.8 \\
28.8 \\
29.3\end{array}$ & $\begin{array}{l}25.1 \\
26.2 \\
28.7 \\
24.6 \\
24.9 \\
27.0\end{array}$ & $\begin{array}{l}1.0 \\
1.5 \\
1.1 \\
4.2 \\
3.9 \\
2.3\end{array}$ & $\begin{array}{l}20 \\
33 \\
32 * * \\
60 \\
40 \\
20\end{array}$ & $\begin{array}{l}25.1 \\
27.1 \\
28.7 \\
24.6 \\
25.2 \\
29.8\end{array}$ & $\begin{array}{l}40 \\
38 \\
33 \\
60 \\
60 \\
60\end{array}$ \\
\hline
\end{tabular}

* Surface temperature rose while standing.

** Fainted twice.

drop began very soon after the erect posture was assumed. In some experiments the surface temperature continued to fall uninterruptedly until a minimum was reached. In others the decline was irregular, being interrupted by periods during which the temperature remained constant or even 


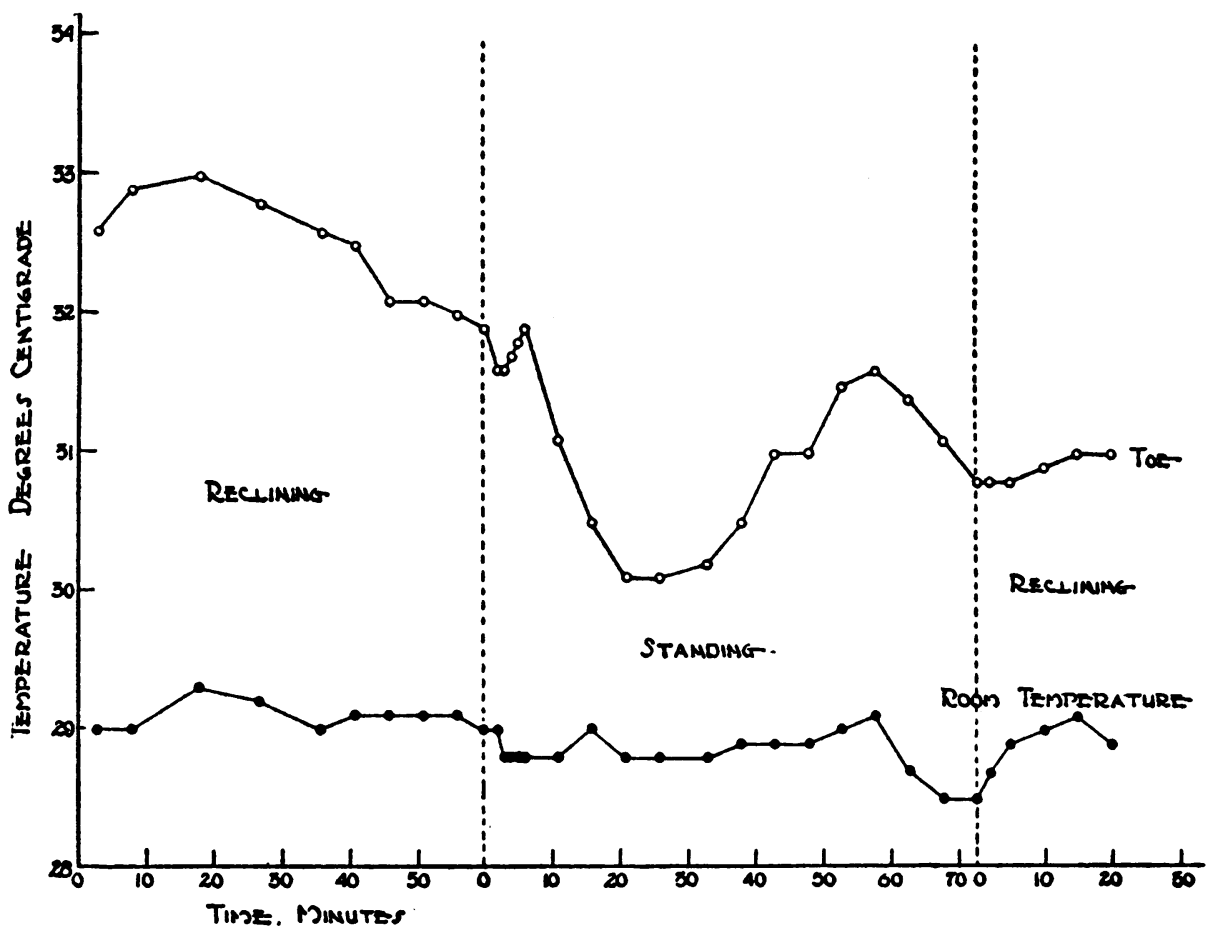

Fig. 1. Changes in the Surface Temperature of the Foot (Toe) During Quiet Standing

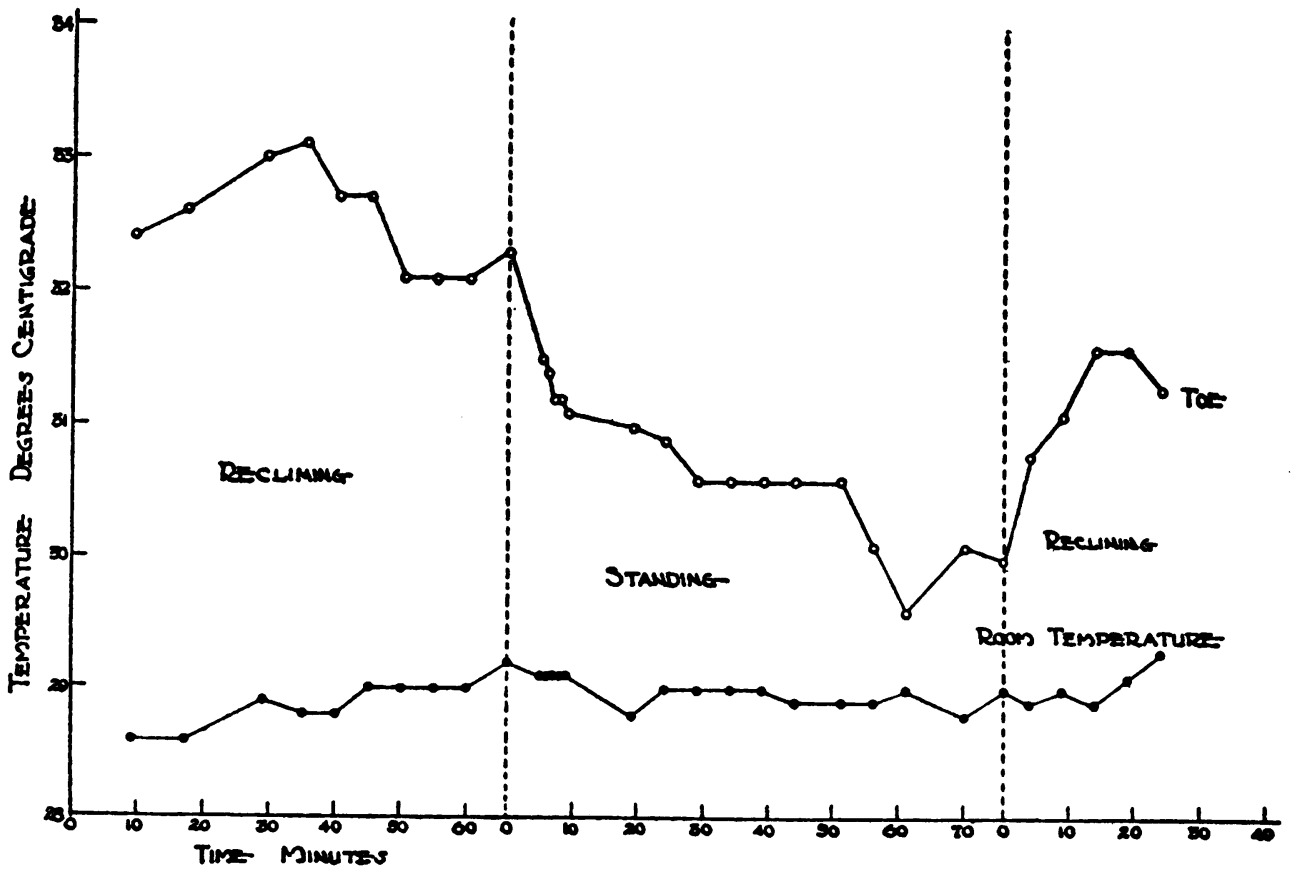

Fig. 2. Changes in the Surface Temperature of the Foot (Toe) During Quiet Standing 


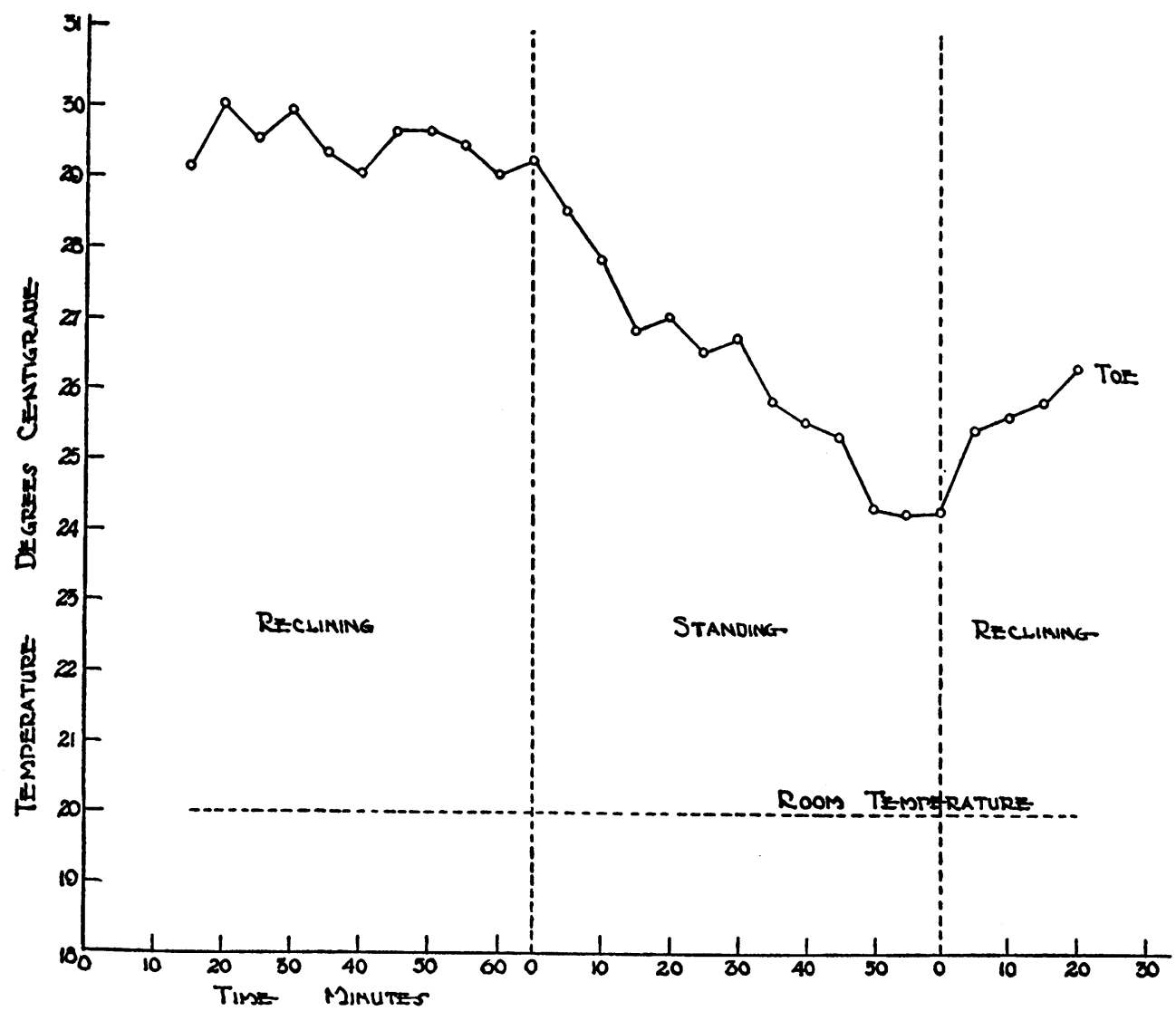

Fig. 3. Changes in the Surface Temperature of the Foot (Toe) During Quiet Standing in a Cool Environment

In this chart the surface temperatures have been adjusted to a room temperature of $20^{\circ} \mathrm{C}$. by the use of Vincent's factor (Vincent, J., La Temperature Climatologique, Ceil et Terre, $2 \mathrm{~d}$ series, $1890,5,515)$.

rose more or less for a variable period (Figure 2). The maximum fall in temperature varied from 0.9 to $4.2^{\circ} \mathrm{C}$., and the time to reach the lowest point ranged from 20 to 70 minutes after the standing position was assumed. In one subject no fall occurred on standing, the temperature rising steadily for 26 minutes from the time she stood, following which it slowly fell until, after 61 minutes of standing, it had returned nearly to its level at the beginning of the standing period. In this experiment, however, the surface temperature of the toe had dropped rather abruptly just before the subject stood. In several experiments it was noted that following the maximum fall there was a greater or less return of the surface temperature toward the initial level (Figure 1). The surface temperatures of the ankle and leg, which are not included in the charts, showed changes similar to those of the toe but of a smaller magnitude. No special difference was noted when

TABLE III

Changes in the surface temperature of the feet (toe) during the erect posture; comparison of the quiet and moving leg

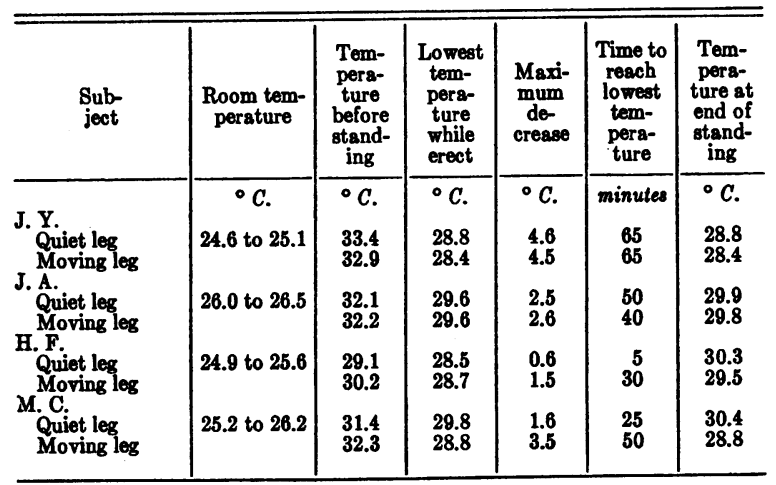


the environmental temperature was lower, except that a lower level of surface temperature was reached than in the warmer environment (Figure 3). In most of the experiments resumption of the reclining position after standing was associated with a return of the surface temperature toward the prestanding level.

When the subject stood quietly on one leg and pedalled with the other, there was a drop in the surface temperature of both feet (Table III) (Figure 4). The fall was sometimes greater in the moving leg, and this leg less often showed a return of the surface temperature toward the ini- tial level as the erect position was maintained. As in the other experiments the quiet leg became cyanotic but the moving leg was lighter in color and pink. The finding of a decrease in the surface temperature of the moving leg was somewhat surprising, as there is every reason to believe that the total blood flow through the moving leg is not only greater but faster than in the quiet leg. In part, the drop in surface temperature may have been due to the cooling effect of movement in the air. The appearance of the leg, however, suggested that in addition to any cooling effect from motion there was an actual decrease in blood flow

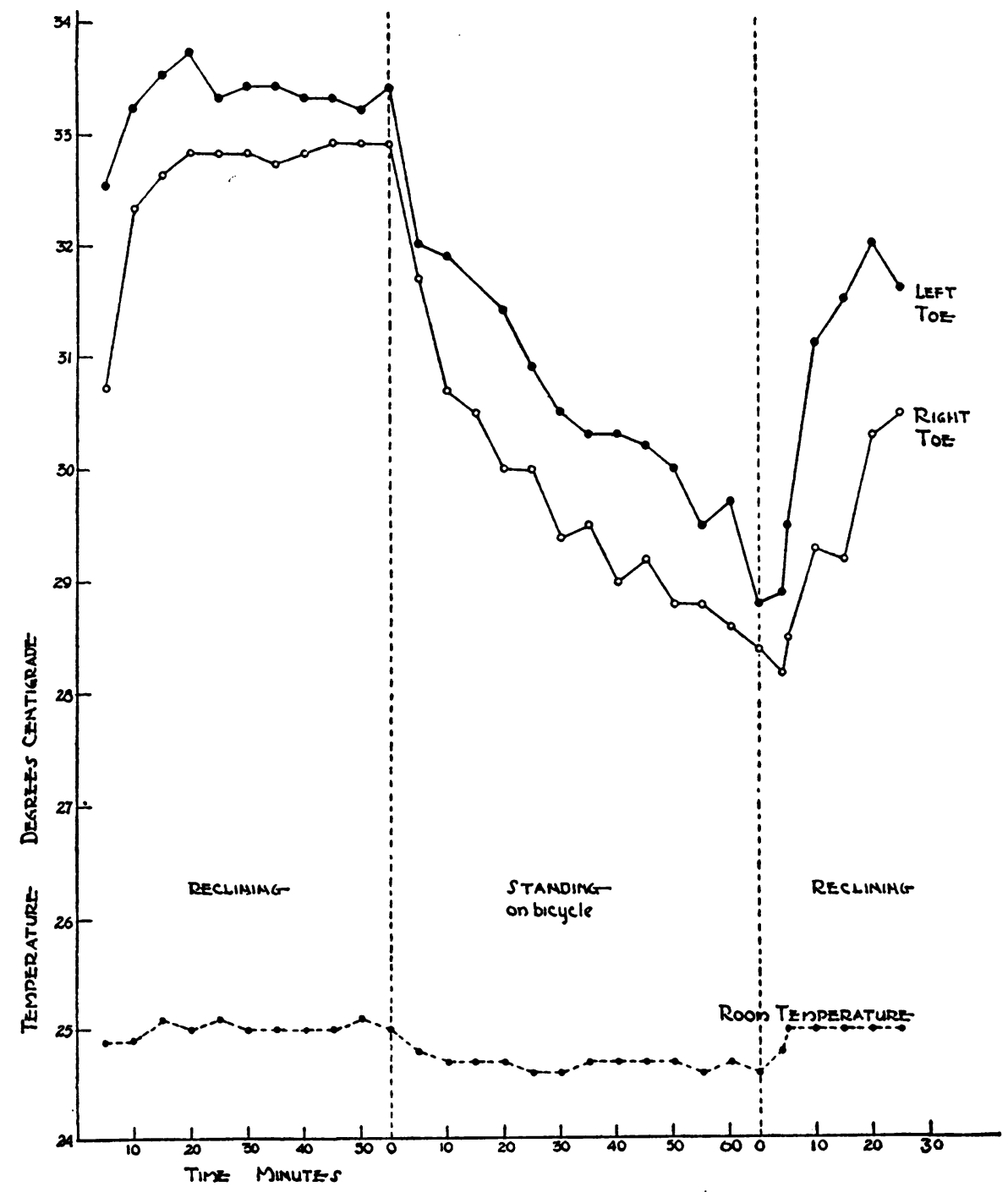

Fig. 4. Comparison of the Changes in the Surface Temperature of the Foot (Toe) in the Quiet (Left) and Moving (Right) Leg in the Erect Posture 
in the skin and subcutaneous tissues in contrast to the presumably much greater flow through the muscles. Therefore, changes in surface temperature are probably a poor index of total blood flow in the actively moving foot and leg.

As an incidental finding in these and certain other related experiments it was observed that venipuncture in either arm or leg was followed by a prompt and significant fall in the surface temperature of the feet (and usually of the legs). The decrease amounted to as much as $2^{\circ}$ and persisted for as long as 15 to 20 minutes. False venipuncture, i.e. piercing the skin with the needle without entering the vein, usually caused a much less or insignificant effect. The drop in surface temperature of the legs and feet following venipuncture is apparently a reflex phenomenon similar to that caused by other physical and mental stimuli. Venipuncture appears, however, to be a more powerful stimulus to vasoconstriction than, for example, a similar degree of pain unaccompanied by injury to a vein, and is a factor for which allowance should be made when venipunctures are performed in conjunction with measurements of surface temperature.

\section{Summary}

Assumption of the erect posture is usually accompanied by a prompt and significant fall in the surface temperature of the feet and legs. This drop occurs in a warm as well as in a cool environment, and in the muscularly active (pedalling) leg as well as in the quiet leg in spite of a presumably greater and more rapid total blood flow in the former.

III. CIRCULATION TIME IN THE QUIET AND MOVING LEG IN THE ERECT POSTURE

The circulation time in the leg in the recumbent and erect positions and the differences in the quiet and moving leg in the latter position were determined as follows. The subjects were three healthy young men. An attempt to include two female subjects failed because of difficulty in performing venipunctures in the foot and ankle of the "moving" leg and the distress caused by the experiment. The subject reclined with the feet and legs exposed to above the knees for an hour or more. After this preliminary period the circulation time in an arm and each leg was measured. The subject then mounted a bicycle so arranged that he stood nearly upright on the left leg while pedalling with the right, keeping the left practically quiet in spite of the action of the other leg. Pedalling against resistance was continued at the rate of approximately 50 cycles per minute for periods of 49 to 69 minutes, except for brief interruptions to inject the test solutions. An attempt was made to measure the circulation time in each leg at the beginning, middle and latter part of each period of standing and in the arm at the end of this period, but was completely successful in only one experiment. In two experiments the circulation time was determined by the injection of sodium cyanide (4) and in one experiment by the injection of either sodium dehydrocholate (5) or saccharin (6). Stop watches were used by two observers to register the time of the "reaction," the average being taken. Unless a definite reaction was obtained a second test was made a few minutes later. During the experiment the surface temperatures of the feet and legs were measured at frequent intervals, but the complicating effects of venipuncture and reactions to the intravenous injections obscure the relation of the changes in surface temperature to posture and exercise.

All the subjects found the procedure a very trying ordeal. When sodium cyanide was used to measure the circulation time in the legs, each injection was accompanied by a period of faintness, dizziness and, in some instances, nausea. This was particularly severe in the case of the left leg (quiet standing position) and may have been related to the large doses which were necessary in these circumstances. As Bock, Dill and Edwards have pointed out (7), with the great slowing of the circulation it is necessary to employ stronger concentrations of the drugs to secure a sharp end point. In one subject, not included in this series, a slough followed the injection of a small amount of cyanide solution ( 2 per cent) into the tissues of the foot outside the vein, with the formation of an ulcer which was very slow to heal. The injection of saccharin caused severe pain along the course of the vein in the leg, followed by faintness and later by a venous thrombosis. Subjects P. D. and A. D. nearly fainted toward the end of the experiment. These com- 
TABLE IV

Circulation time in arm* and each leg** while reclining and while erect with left leg motionless and right leg moving

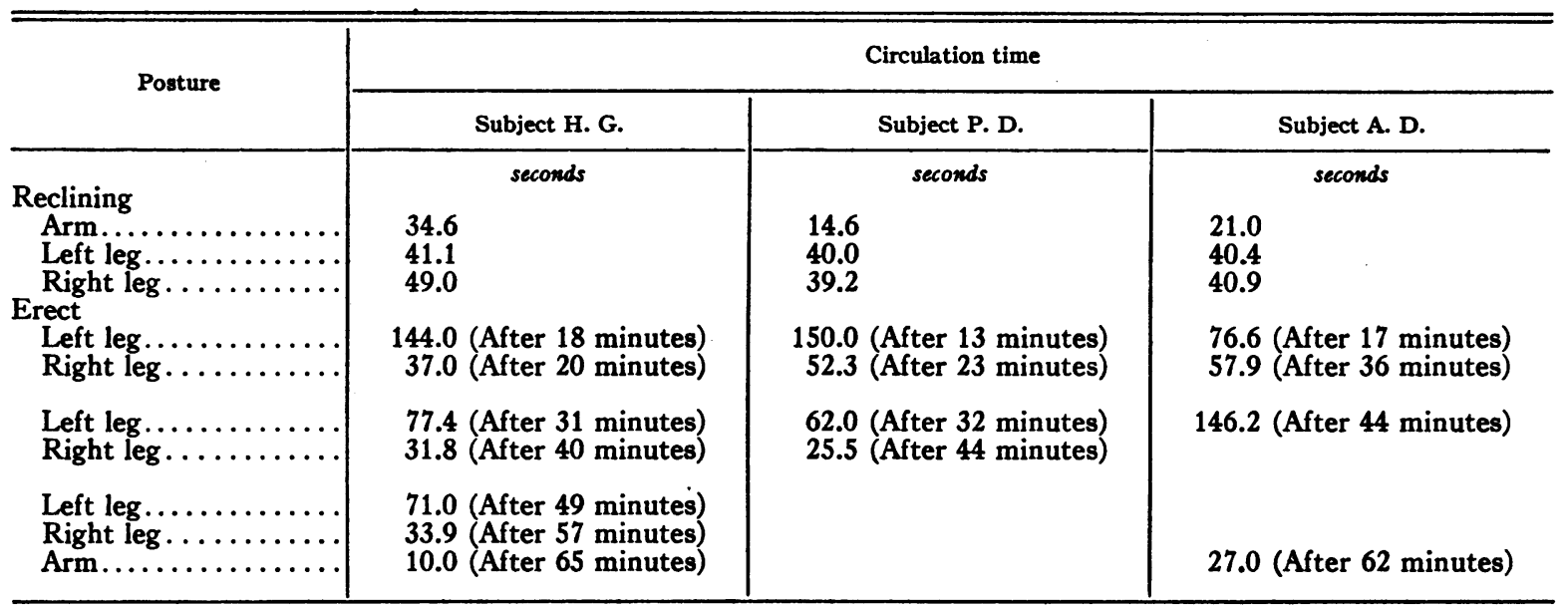

* Arm to carotid.

** Leg to carotid.

plications may have caused some irregularities in the results.

The results are summarized in Table IV. In all three subjects the circulation in the left (quiet) leg was much slower in the erect than in the reclining position, the maximum slowing occurring in Subject H. G., in whom the circulation time was almost four times as long 13 minutes after the standing period began as it had been while reclining. In all three subjects the circulation while erect was much slower in the left (quiet) leg than in the right (moving) leg. The latter showed, in general, a faster circulation while erect and moving than when reclining and quiet. In two determinations the circulation time in the right moving leg was slightly longer when erect than when reclining, but it was necessary to stop the movement of the leg while the solution was injected, and some delay in this maneuver may have allowed the circulation to slow somewhat. In two of the subjects the circulation in the left (quiet) leg was much slower in the early than in the later part of the standing period. In Subject A. D., the circulation time in the quiet left leg was longer in the later part of the standing period than near the beginning. At this time, however, he was faint and suffering considerable pain.

\section{Summary}

In the erect posture the circulation time in the quiet leg is much longer than in the reclining position. On the contrary, the circulation time in the moving leg is often shorter than in the reclining position, and hence often several times shorter than in the opposite, quiet leg.

IV. THE INFLUENCE OF VASODILATATION ON THE CHANGES IN COMPOSITION OF THE BLOOD

\section{WHICH OCCUR ON STANDING}

In order to study the part played by vasoconstriction in the changes in the blood which accompany the erect posture, we abolished or lessened it, and compared the ensuing changes in the blood in the feet and legs during standing with those which occurred when vasoconstriction was present.

Various methods for obtaining a vasodilatation in the feet and legs were considered, but for several reasons the one which seemed most suitable and was adopted was that of heating the hands and arms (8). This procedure will produce in most normal subjects a considerable degree of vasodilatation in the feet and legs, which can be measured by determining the surface temperature.

The complete study consisted of four distinct experiments, as follows: First, a control experi- 
ment to determine the maximum dilatation (increase in surface temperature) in the feet and legs, produced by heating the arms with the subject reclining. Second, a control experiment with the subject standing quietly, to determine whether heating of the arms could overcome the drop in surface temperature (decreased blood flowvasoconstriction?), which we have shown occurs in the erect posture. Third, a determination of the degree of concentration of the blood (foot) and the change in leg volume, which occurred when the subject stood for a given period without vasodilatation. Fourth, a determination of the degree of concentration of the blood (foot) and the change in leg volume when the subject stood for a similar period with vasodilatation.

Two young healthy men served as subjects. The individual experiments were performed on separate days at varying intervals. In all the experiments the subjects first reclined with the feet and legs exposed to above the knees. The surface temperatures at the base of the great toe, over the external malleolus and just below the knee were recorded with a thermocouple, exactly the same location being tested each time. The room temperature was maintained as constant as possible in the neighborhood of $20^{\circ} \mathrm{C}$., with a range of $2^{\circ} \mathrm{C}$., and was recorded by a mercury thermometer suspended near the feet and legs. The hands and arms were heated by being immersed to above the elbows in water at a temperature of $44^{\circ} \mathrm{C}$. or more. White enamel basins with covers were used, and the temperature was maintained by the addition of hot water at suitable intervals. Samples of blood were drawn without stasis, and those for serum protein and colloid osmotic pressure determinations under oil. The relative cell volume (hematocrit) was measured with Wintrobe hematocrit tubes (9) using heparin as an anticoagulant. The volume of the leg was measured as previously described.

In the first control experiment the subjects reclined until the surface temperatures were relatively constant. The hands and arms were then immersed in the hot water. Both subjects showed an increase in the surface temperature of the toes from a "pre-heating" level of 26.1 and 26.9 to 30.5 and $30.0^{\circ} \mathrm{C}$., an increase of 4.4 and $3.1^{\circ} \mathrm{C}$., respectively. The increase began 11 and $7 \mathrm{~min}$ - utes after the hands and forearms were immersed, and the maximum was reached in 37 and 41 minutes. In both subjects the period before the temperature began to rise was marked by an initial drop. An initial drop in the surface temperature of the toe when the hands and forearms were first immersed in hot water, amounting to as much as $2^{\circ} \mathrm{C}$. and persisting for as long as 11 minutes, often occurred in these experiments. In neither subject did the surface temperature of the toe reach $32^{\circ} \mathrm{C}$., which is considered to indicate complete vasodilatation (Landis). This is probably explained by the fact that the temperature, at the base of the toe was measured instead of at the base of the toe nail, where there is a richer anastomosing circulation. The ankle and leg showed a slight rise only.

In the second control experiment, after the preliminary reclining period, Subject W. H. stood and immediately immersed his hands and forearms in the hot water. Contact of the feet with the floor was prevented by a blanket. Quiet standing was maintained for a period of 41 minutes, during which time the surface temperature of the toe rose from the prestanding level of 24.8 to a maximum of $30.6^{\circ} \mathrm{C}$. an increase of 5.8 degrees, 27 minutes after standing began. The rise started 11 minutes after standing and heating the hands and forearms began, the preceding interval being marked by a rather sharp drop of $1.5^{\circ} \mathrm{C}$. To lessen this initial drop, the forearms and hands of the second subject (J. P.) were placed in hot water for 38 minutes before he stood. He then. stood, keeping the forearms in hot water constantly for 36 minutes. While he still reclined with the arms in hot water, the surface temperature of the toes rose from $27.1^{\circ} \mathrm{C}$. to a maximum of 29.9 degrees, 30 minutes after heating the forearms began. On standing, a drop of $1.1^{\circ} \mathrm{C}$. occurred over a period of 9 minutes. The temperature then rose to a maximum of $30.9^{\circ} \mathrm{C}$., 19 minutes after he stood, an increase of 3.8 degrees over the preheating period. Thus, heating the forearms and hands was able not only to overcome the drop in surface temperature which occurs on standing but was capable of increasing the surface temperature significantly above the preliminary reclining period. In this second experiment, in which the subject stood, the surface 
temperatures of the ankle and of the leg not only showed a smaller rise than that of the toe but often remained constant or even dropped slowly but steadily.

In the third and fourth experiments, the effect of standing on the concentration of blood in the feet and on the leg volume, with and without vasodilatation, were compared. The subjects reclined until the surface temperature of the exposed feet and legs was quite constant and the concentration of blood in the upper and lower parts of the body had become equalized. The venous pressure in the arm was then measured, a specimen of blood was removed for the various analyses, and the volume of the leg measured. The subject then stood quietly for a period of 45 minutes, during which the changes in surface temperature were recorded. At the end of the standing period the venous pressure at the ankle was measured, a second sample of blood was drawn and the volume of the leg measured again. In Experiment 3, the hands and forearms were not heated. In Experiment $4, W . H$. immersed the hands and forearms in hot water immediately on standing. With Subject J. P. the forearms and hands were immersed for 25 minutes before he stood, as well as during the standing period.

In these experiments the complicating effect of venipuncture, which causes a drop in the surface temperature of the feet and legs, was introduced. Because of this the surface temperatures at the time of standing were lower than in the control experiments. With Subject W. H., the temperature of the toe at the time of standing without vasodilatation was $22.0^{\circ}$ and during the standing period it fell gradually to $20^{\circ} \mathrm{C}$. With vasodilatation the temperature at the beginning of standing was $21.9^{\circ}$ but it dropped irregularly to $21.2^{\circ}$ C. over a period of 18 minutes, before it rose to a maximum of $23.2^{\circ} \mathrm{C}$., about 3 degrees higher than in the experiment without vasodilatation. However, he was able to stand with the arms in hot water for a period of 30 minutes only before syncope stopped the experiment, and thus for only about 10 minutes of the standing period was the temperature of the toe much higher than in the experiment without vasodilatation. With Subject J. P. the surface temperature of the toe while standing without vasodilatation ranged from 21.5 to $22.2^{\circ}$. On standing with the arms heated the surface temperature of the toe rose from about $23^{\circ}$ to a maximum of $28.2^{\circ}$ and during the entire standing period was considerably higher than without vasodilatation, the maximum difference being about $7^{\circ} \mathrm{C}$. In both subjects the surface temperature of the leg fell slightly on standing in spite of heating of the arms. The ankle showed a little rise. When the arms and hands were heated a vasodilatation was shown by a pinkness of the feet which was in sharp contrast to the cyanosis which appeared in the absence of heating. This was less noticeable in Subject W. H. Both subjects sweated profusely during the vasodilatation and both found the experiment a very trying ordeal.

The changes in the composition of the blood were exactly opposite in the two subjects (Table V). Subject W. H. showed a slightly greater concentration of the blood on standing with vasodilatation than without, as shown by the concentration of total protein and albumin and the increase in colloid osmotic pressure and relative cell volume. The difference in total protein was so slight, however, as to be of little significance. Changes in the concentration of globulin were the reverse of those of albumin and total protein, probably the result of a difference in the loss of the two protein fractions through the capillary wall (2). In keeping with the greater concentration of the blood during vasodilatation the increase in leg volume was greater with vasodilatation than without. Venous pressure during standing was essentially the same with and without vasodilatation. Subject J. P., in contrast to Subject W. H., showed less concentration of the blood with vasodilatation. The difference was consistent and was reflected in the changes in total protein, albumin, globulin, colloid osmotic pressure and relative cell volume. There was, however, little difference in the increase in volume of the leg in the two experiments, though the slight difference noted was in keeping with the changes in the blood. The fact that there was nearly the same increase in leg volume, in spite of less concentration of the blood and excessive sweating, suggests that the total filtrate was greater with vasodilatation. As in the case of Subject W. H., there was no difference in venous pressure, with or without vasodilatation. 
TABLE $\mathbf{V}$

The concentration of plasma proteins, colloid osmotic pressure, relative cell volume, venous pressure and volume of the leg in the reclining and standing still positions, with and without vasodilatation.

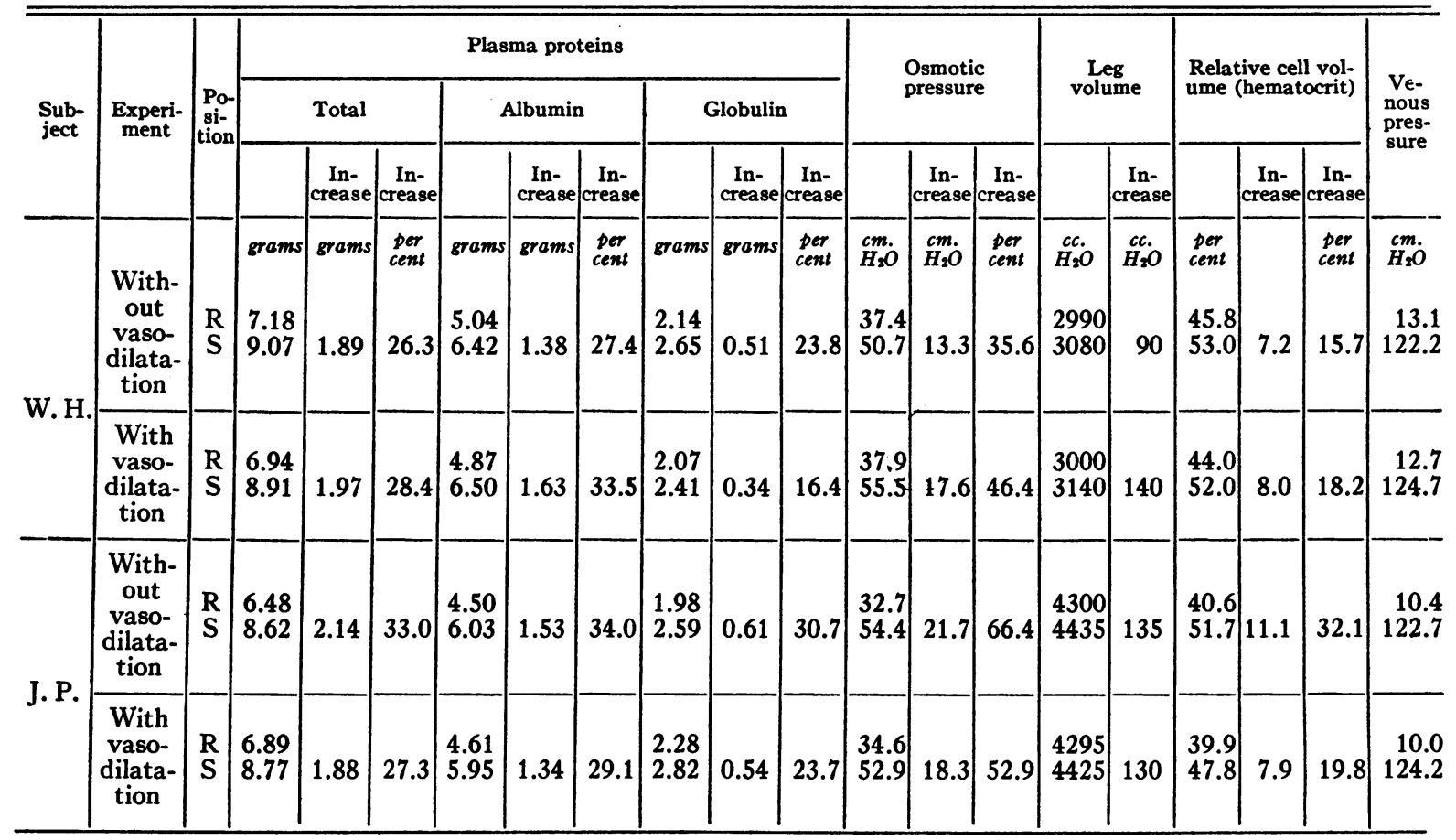

The inconsistent results in the two subjects may have been due, in part, to variations in the length of the standing period, the vasomotor effects of venipuncture, sweating and the influence of syncope. Unfortunately the rigors of the experiment prevented the performance of a larger series, which might have avoided some of these difficulties.

\section{Summary}

Heating of the forearms and hands was accompanied by a rise in the surface temperature of the feet (toe) with the subject erect, overcoming the drop in surface temperature which occurs in the quiet standing posture.

Vasodilatation resulted either in a greater or a lesser concentration of the blood in the feet and legs in the erect posture than occurs without vasodilatation. In either case the total volume of fluid filtered into the tissues of the leg appeared to be greater with vasodilatation.

\section{DISCUSSION}

The results of these four studies indicate the essential difference in the mechanisms which tend to limit the amount of fluid which accumulates in the dependent tissues during quiet standing and active exercise in the erect posture, respectively. In addition they emphasize the importance of the circulatory changes which accompany the assumption of the erect position. As was pointed out in the introduction, one of the primary factors concerned in limiting the loss of fluid from the blood in the standing-still position is an increase in the concentration of the blood in the dependent parts. This is aided by a decrease in the velocity and volume flow of blood in the feet and legs, shown by the studies of surface temperature and circulation time. The reduced velocity permits a greater loss of fluid per unit of blood with a greater local concentration and a higher colloid osmotic pressure, while the decreased flow limits the total amount of fluid filtered. On the contrary, in the moving leg the decrease in velocity does not occur, and the circulation time may be even shorter than in the reclining position. Some inability to maintain these changes in the circulation in the quiet standing position is indicated by the frequent occurrence of a secondary rise in the surface temperature as the subject continued to 
stand, as well as by the fact that two subjects showed a much greater slowing of the circulation in the quiet leg during the first part of the standing period than later.

Bock, Dill and Edwards (7) have suggested that an increased circulation time in the standingstill position indicates, but does not prove, the existence of a smaller blood flow, since a great increase in the vascular bed might compensate for the slower circulation. Such a possibility is suggested by the great increase in size and number of open capillary loops in the erect posture. However, the great drop in surface temperature of the feet and legs in the standing-still position suggests that in spite of an increase in the vascular bed there is an actual decrease in blood flow as well as in the velocity of the circulation. The changes in the circulation represented by the drop in surface temperature and increased circulation time appear to be brought about, in a large measure at least, by a vasoconstriction, since vasodilatation prevented the drop in surface temperature which usually occurs on standing and presumably lessened the slowing of the circulation which occurs under the same conditions. This vasoconstriction does not appear to include the capillaries, although the latter seem still capable of constriction. Although the effect of vasodilatation on the concentration of the blood in the legs was variable, these results are believed to be consistent with the effect which vasodilatation might have under conditions of normal activity. Vasodilatation usually causes a more rapid blood flow. This should result in a smaller loss of fluid per unit of blood and hence less concentration of blood locally. At the same time, however, it causes a rise in capillary pressure, which tends to cause a greater filtration of fluid and hence a greater concentration of the blood. It appears, therefore, that in any given case the net result would depend on the relative importance of these two effects and might vary depending, among other things, on the degree and duration of vasodilatation. It seems possible that with maximum dilatation so much fluid might be filtered that blood flow would be significantly impeded by the increased viscosity, a state approaching true stasis (Landis). In this case the local concentration of blood would be greater than without vasodilatation. In other in- stances, the influence of increased flow might predominate and cause less concentration of blood locally than occurs without vasodilatation.

As far as the total volume of fluid filtered into the tissues is concerned, it should be greater with vasodilatation (absence of vasoconstriction). Even though the more rapid blood flow in the latter case resulted in a smaller loss of fluid per unit of blood, the greater total flow should cause a larger total filtrate than occurs with vasoconstriction. Should the increased capillary pressure, occurring in the absence of vasoconstriction, cause a greater loss of fluid per unit of blood, the total filtrate would again be greater. In either case the conditions are similar to those existing during exercise in the erect posture. As we shall see, however, during exercise lymph drainage is able to remove the excessive filtrate, so that the volume of the leg increases but little or may even decrease. When vasodilatation occurs during quiet standing, lymph drainage is probably less able to remove the excess fluid, and the local accumulation would be greater than in the presence of the usual vasoconstriction.

In contrast to the standing-still position there is less concentration of the blood in the muscularly active leg in the erect posture. This suggests that less fluid is filtered from the blood in the erect posture when the legs are moving. Furthermore, the active leg showed a smaller increase in volume, which again suggests the filtration of a smaller amount of fluid. However, neither the lesser increase in the concentration of the blood nor the smaller increase in leg volume, in themselves, prove that a smaller amount of fluid was filtered from the blood into the tissues of the active leg. Moreover, all the evidence from other sources is to the contrary. Muscular activity is accompanied by a hyperemia, an increased intracapillary pressure and the production of osmotically active metabolic products which greatly increase filtration (10). According to Landis (11) fluid leaves the blood several times more rapidly during muscular activity than it does at rest under a venous pressure of $80 \mathrm{~cm}$. of water. Under the conditions of our experiments, muscular activity and a high environmental temperature must have resulted in a greatly increased passage of fluid from the blood to the tissues. Although the 
smaller increase in concentration of the blood in the " moving" leg indicates a smaller loss of fluid per unit of blood, a greater total blood flow would cause a greater total volume of filtrate. Furthermore, the smaller increase in volume of the " moving" leg, by limiting the rise in tissue pressure, would of itself permit a greater volume of fluid to be filtered. It would seem, therefore, that the smaller accumulation of fluid in the moving leg must be the result of a more rapid removal of the filtrate. This rapid removal is most probably accomplished by lymph drainage. It is known that muscular activity and an increased venous pressure cause an increase in the flow of lymph (12). At the same time they hinder resorption. An increased lymphatic drainage during muscular activity has been clearly shown in normal and edematous animals (dogs) by Weech, Goettsch and Reeves (13). In their experiments the onset of activity (walking) was accompanied by a greatly increased flow of lymph, which drained the leg of accumulated interstitial fluid and, in edematous dogs, gradually reduced or abolished the edema. Thus, with muscular activity, the excessive accumulation of fluid in the dependent parts during the erect posture is prevented, not so much by limitation of filtration as by the more rapid removal of an even greater volume of fluid than is filtered on quiet standing. ${ }^{5}$ Since the volume of fluid removed by lymphatic drainage is presumably returned to the circulation rapidly, the reduction in total blood volume at any one time is probably much less than when standing still.

\section{SUM MARY AND CONCLUSIONS}

In summary, the exchange of fluid between the blood and tissues, primarily controlled by capillary and colloid osmotic pressure, is greatly influenced by a number of secondary factors, particu-

\footnotetext{
s Although the vasoconstriction and circulatory changes which we have discussed are most evident in the standingstill position and contribute greatly to the special mechanism by which the loss of fluid into the dependent tissues is limited in that position, they are undoubtedly effective during active movement as well and, under pathologic conditions especially, may modify the mechanism which controls the accumulation of fluid in the legs during exercise.
}

larly by posture. The great tendency to edema in the quiet erect posture is opposed by a rising colloid osmotic pressure and by an increasing tissue pressure in the feet and legs. These forces are aided by a decrease in the volume and velocity of the circulation in the legs. With muscular activity an even greater volume of filtrate than occurs on quiet standing is prevented from accumulating by a more active lymphatic drainage. Variations in these secondary factors will influence the exchange of fluid between the blood and the tissues and, in the presence of even slight changes in the serum proteins and capillary pressure, may determine the appearance or non-appearance of edema. Due consideration must be given to the influence of these secondary factors in interpreting the effect of abnormal variations in the fundamental forces concerned, especially under conditions of changing activity such as exist in ambulatory patients. For these reasons it is inadvisable to define too strictly the critical level of the serum proteins or venous pressure in relation to the pathogenesis of certain forms of edema.

\section{BIBLIOGRAPHY}

1. Krogh, A., Landis, E. M., and Turner, A. H., The movement of fluid through the human capillary wall in relation to venous pressure and the colloid osmotic pressure of the blood. J. Clin. Invest., 1932, 11, 63.

2. Youmans, J. B., Wells, H. S., Donley, D., Miller, D., and Frank, H., The effect of posture (standing) on the serum protein concentration and colloid osmotic pressure of the blood from the foot in relation to the formation of edema. J. Clin. Invest., 1934, 13, 447.

3. Landis, E. M., Jonas, L., Angevine, M., and Erb, W., The passage of fluid and protein through the human capillary wall during venous congestion. J. Clin. Invest., 1932, 11, 717.

4. Robb, G. P., and Weiss, Soma, A method for the measurement of the velocity of the pulmonary and peripheral venous blood flow in man. Am. Heart J., 1933, 8, 650 .

5. Tarr, L., Oppenheimer, B. S., and Sager, R. V., Circulation time in various clinical conditions determined by the use of sodium dehydrocholate. Am. Heart J., 1933, 8, 766.

6. Fishberg, A. M., Hitzig, W. M., and King, F. H., Measurement of circulation time with saccharin. Proc. Soc. Exper. Biol. and Med., 1933, 30, 651.

7. Bock, A. V., Dill, D. B., and Edwards, H. T., Relation of changes in velocity and volume flow to changes in posture. J. Clin. Invest., 1930, 8, 533. 
8. Landis, E. M., Vasodilatation in the lower extremities in response to immersing the forearms in warm water. J. Clin. Invest., 1932, 11, 1019.

9. Wintrobe, M. M., A simple and accurate hematocrit. J. Lab. and Clin. Med., 1929, 15, 287.

10. Barcroft, Joseph, and Kato, T., Effects of functional activity in striated muscle and the submaxillary gland. Phil. Trans. Roy. Soc., London, 1915-16, 207, 149.
11. Landis, E. M., Capillary pressure and capillary permeability. Physiol. Rev., 1934, 14, 404.

12. White, J. C., Field, M. E., and Drinker, C. K., On the protein content and normal flow of lymph from the foot of the dog. Am. J. Physiol., 1933, 103, 34.

13. Weech, A. A., Goettsch, E., and Reeves, E. B., The flow and composition of lymph in relation to the formation of edema. J. Exper. Med., 1934, 60, 63. 